\title{
COMPARISON OF THE FIRST YEAR LEARNING OUTCOMES OF DUAL AND NONDUAL STUDENTS IN THE LIGHT OF THE INPUT COMPETENCE SURVEY
}

\author{
Róbert Pap-Szigeti ${ }^{1,2}$, \& Erika Török ${ }^{1}$ \\ ${ }^{I}$ GAMF Faculty of Engineering and Computer Science, John von Neumann University, \\ Kecskemét (Hungary) \\ ${ }^{2}$ Bolyai János Secondary Grammar School, Kecskemét (Hungary)
}

\begin{abstract}
The number of students taking part in, and the courses involved in dual education have multiplied since the dual education was introduced. At our university, in the last seven years, some hundreds of students have participated in the training based on the German model, implemented in cooperation with partner companies.

Based on our assumptions at the beginning of the dual training and the experiences accumulated during the training we assume that in general, more motivated students, the ones who are eager to learn and meet the requirements chose this form of education.

The double filter (university and company) makes it possible to choose the best students. The strong selection and the stricter education criteria set by the form of the training (the required progress according to the sample curriculum) results in the students' achievements which are significantly better than the non-dual students' results.

Thanks to the input surveys regarding the dual and non-dual students which have been conducted since 2010 in our institutions, it is possible to measure the competence of dual and non-dual students at the beginning of the training, and we can also get information about the differences between the two groups and compare the achievements of dual students with the non-dual students. This examination gives a chance to examine how successful the training was for the dual students. The sample of our research consisted of the first year BSc full time students $(n=1,341)$. We applied the sample adjustment according to the points of the entrance tests when we analysed the achievements of the different training systems. In our presentation, we demonstrate the main areas of the competence survey, the results reached in those areas, the differences between the achievements in those areas, the impact of the input results on the success of learning (the impact of the differences on the results of the first year) in case of dual and non-dual students. We highlight those areas which significantly influence the study results regardless of training forms.
\end{abstract}

Keywords: Higher education, dual training, competence survey.

\section{Introduction}

There is an increasing demand for highly qualified experts who meet the requirements of economy. The higher education must overcome these challenges efficiently. The renewed strategic programme for higher education adopted by the European Union sets an aim to be reached that $40 \%$ of young people should obtain Bachelor's or Master's degree, and it is predicted that by the year 2025 half of the total number of jobs will require higher education qualification. Higher education must ensure to be inclusive, that is, the institutions of higher education should not be ivory towers, but civilian learning communities which are connected to the local society (COM 2017, 247 final). At the same time it is worth mentioning that a portion of students who gets admitted to higher education does not have the appropriate knowledge in basic skills (reading-writing, arithmetic skills), they lack the experience in independent learning; neither the prospective students nor their parents know what situations, tasks to be solved, expectations to be met they can expect in higher education.

According to the strategy of the Union the higher education institutions must make it possible for the students to obtain skills and experiences through activities in which they must solve real life problems, and also they have to be given the opportunity to the work-based learning. The higher education institutions endeavour to fulfil these requirements in various ways. The dual training is a type of learning system applied 
at several universities. In German speaking countries, this training is known as "Dual" in English speaking countries as "Dual" or "Cooperative" Education. Further synonyms for the dual training are "co-op practice", "experiential learning”, “co-op internship", "work integrated learning", "work based learning" or "university-industry partnership" (Nagy, Török and Angeli 2019). In Hungary the most well-known names used for this practice oriented training are dual, cooperative or partnership training.

At John von Neumann University (formerly Kecskemet College) students have been able to study in this type of training since 2012.

At our university based on the collaboration with employers we attempt to customise our curricula to the demands of the corporate demands and also eminently fulfil the academic requirements and Training and Output Requirements.

In the last 7 years we have gathered a lot of experiences to judge the efficiency of the training. We have indicators regarding the number of courses in which it was possible to choose the dual training (at the beginning there were two basic courses, at the moment we have nine), the number of students who participated in dual training (in the first year, there were 24 students, at the moment, we have 328), the number of collaborating companies (there were 2 collaborating companies at the beginning, and at the moment, we have 82 partners) and also about the activities of the involved companies. We have conducted a student satisfaction survey (Török and Kovács, 2016; Török, Pap-Szigeti, Ailer and Palkovics 2014), and we have come to the conclusion that the students learning outcome numbers is an important indicator of the efficiency of the dual training. In our forgoing investigations we have compared the results of the dual students to the nondual students, who studied at the same study programme, in the same semester, and we found that despite the bigger requirements which the students taking part in the dual training had to meet (placement time at the company, less free time, more responsibility at the workplace) the dual students reached better results. Similar results are reported at the research conducted at Óbuda University (Pogatsnik, 2018). The question emerged when comparing the results of dual and nondual students to what extent we should take into consideration the students' secondary school learning outcomes (entrance examination scores) and the data of the input competence survey. At our university we conduct input competence survey in which all the full time BSc students take part as it is a criterion in the curriculum.

\section{Being admitted and integration - Dual students at university}

There is an important factor which should be mentioned in connection with getting into the dual education system, which might have a great impact on the students' learning outcomes later. The dual students can get into the training through two step screening procedure. The initial screening procedure is - in accordance to the state requirements- that the students are admitted to the university based on their secondary school learning outcome scores. The second screening comes after the students have submitted their application to the "dual" company, in this part; the students take part in a recruitment procedure required by the company to which they applied. It can happen that some companies apply a recruiting procedure consisting of several steps. The ultimate goal of this procedure is that the applicants and the companies get to know each other. The companies take into consideration the students learning outcomes, their aptitude, skills, personality, as well as their foreign language skills are tested orally and in writing. Some companies assess how the applicants can solve tasks individually and in groups. Therefore the students who take part in dual education participate in a stricter filtering procedure than the nondual students. After the students' applications have been accepted, the students sign the contract with the company, and the students' integration into the company starts (getting acquainted with the company, its profile, physical environment, culture, employees, professional tasks etc.) These can be strong motivational forces, which can support the students' professional engagement, commitment and professional identity.

\section{The hypotheses of the research}

In the introduction, we have presented the main features of the dual training and the way students can get into it. Based on the factors which were mentioned especially, the stronger selection, the stricter subject criteria and the social influences we suppose that

(1) There is significant difference between the dual and nondual students' abilities/skills and self-reflexion even at the beginning of their university studies.

(2) As a result of the above mentioned effects and the measurable differences there will be significant differences between the learning outcomes of the dual and the nondual students.

The stronger entrance selection does not mean that all the students who do not take part in the dual education have lower skill levels or self-reflection than the dual students. Therefore in our examination we compare the dual students' learning outcomes with the learning outcomes of a subsample of the students 
studying in the traditional system which has similar distribution based on the skill levels and motivation to skill levels and motivation of the dual students.

(3) The results of the input competences predict the learning success at university - regardless of the form of the form of education.

(4) According to this hypothesis the students who do not take part in the dual education; however, they have high level of cognitive skills and self-reflexion levels have same chances to acquire knowledge successfully as dual students.

\section{Methods}

\subsection{The sample}

The research and collection of data organised by the university gave the possibilities to examine these hypotheses. The sample of this examination consisted of the full time BSc students enrolled between 2016 and $2018\left(n_{1}=1341\right)$. The students were selected who took part in the input competence survey $n=1187$ ) and still study at the university. Table 1 shows distribution of the sample according to year and course.

Table 1. The sample division according to the year of enrolment and course types.

\begin{tabular}{llllll}
\hline \hline education form & 2016 & 2017 & 2018 & total & "dropouts" \\
\hline \hline dual & 80 & 99 & 98 & 277 & 9 \\
\hline nondual & 330 & 254 & 326 & 910 & 100 \\
\hline \hline
\end{tabular}

The entrance exam scores are significantly higher in case of the dual students than the students who do not take part in the dual education (in case of the students enrolled in 2016 the difference in means is 26.4 points; $t=5.01 ; p<0.001$. In case of the students admitted in 2017 the difference between the means is 19.0 points; $t=4.613 ; p<0.001$. In case of the students admitted in 2018 the difference in means is 26.3 points; $t=5.648 ; p<0.001$. The difference in standard deviances is not significant in any years).

For investigating the hypothesis (3) we selected the subsample of nondual students which showed similar distribution based on the entrance scores, the results of the input survey for measuring cognitive skills and the distribution of the students by year $\left(n_{\text {dual }}=270 ; n_{\text {nondual }}=263\right)$.

\subsection{Instruments and procedure}

We used the instrument which had been used at John von Neumann University consisting of a digital test and a questionnaire (Hercz, Koltói, Pap-Szigeti and Török 2014). The reliability of the tests (Cronbach's alpha) was acceptable for every year group (every subtest was above 0.90 and for the whole test it was between 0.92-0.94 in every examined year).

The tasks of the test measured (reading comprehension, writing), thinking skills (solving mathematical problems, conceptual systematization, inductive thinking, understanding interrelations).

The test measured some features of verbal memory and metacommunication. In the questionnaire students reflect their own communication, reading comprehension, and general mental skills. We give a feedback to the students on the results of all tests in percentages (that is $100 \%$ means maximal points).

The survey is conducted every year during the registration week. The students can complete the online test; answer the questions within the given timeframe in the time slot chosen by them. They have 90 minutes to complete the tasks and fill in the questionnaire. The test and the questionnaire are presented on general purpose individually developed software (Pap-Szigeti 2018).

We used different additional data to examine our hypotheses beyond the data provided by the test. We examined other data which were recorded in the learning system, for example, the secondary school learning outcome scores, the students' grade average at the of the first year. In addition, the number of acquired credits in the last semester and the number of active semesters were also analysed.

\section{Results}

The hypothesis (1) was justified because the dual students' cognitive skills are in general more developed than that of the nondual students. The differences between the two groups considering the 3 years are significant but not really big. The average of the dual students is $68.6 \%$ points, nonduals 65.3 points $(t=2.322 ; p=0.021)$. 
In some fields there have been significant differences between the two subsamples. In some fields dual students reached significantly better results nondual students. The fields which show significant differences and the degree of the difference are the following:

- Solving mathematical problems $9.3 \%$ point difference

- inductive thinking $7.2 \%$ difference

- systematisation skills 6,0\%points difference

- concept abstraction $2.7 \%$ points difference

Besides cognitive fields (in relationship with those) the self-reflection regarding the thinking skills is significantly $(4 \%)$ higher in case of dual students. This indicator of self-respect works as learning motivation during learning later.

Taking into consideration the learning outcome average of the first school year, there has not been found a significant difference between the students who study in the traditional and in the dual training in case of students admitted in each individual year. In addition the average of the whole sample does not show a different picture either (the first three years were examined and it was found that the average of the nondual students is 3.57, and the dual students reached average of 3.58).

However, the credit indexes of the last completed semester showed that dual students gained remarkable advantage over nondual students (Table 2). The difference almost reached the significance level in the first two years, as regards the data of the three years together the difference becomes significant, which justifies the hypothesis (2).

Table 2. Comparison of the credit indexes at the end of the last completed semester according to the education form.

\begin{tabular}{llllll}
\hline \hline education form & $\begin{array}{l}\text { enrolled } \\
(\mathrm{N})\end{array}$ & 2016 & $\begin{array}{l}\text { enrolled } \\
(\mathrm{N})\end{array}$ & $\begin{array}{l}2017 \\
\text { enrolled } \\
2018(\mathrm{~N})\end{array}$ & $\begin{array}{l}\text { three } \\
\text { total }(\mathrm{N})\end{array}$ \\
\hline \hline dual & 3.84 & 3.76 & 3.54 & 3.71 \\
\hline nondual & 3.60 & 3.47 & 3.24 & 3.42 \\
\hline & $t=1.132$ & $t=1.751$ & $t=1.942$ & $t=2.830$ \\
& $p=0.259$ & $p=0.081$ & $p=0.053$ & $p=0.005$ \\
\hline \hline
\end{tabular}

Based on the currently available data we can analyse the predictive power of the entrance exam scores and some fields of the competence survey. The correlations of variables were analysed with linear regression where the dependent variable was the scores of first academic year, and the independent variable was the entrance examination scores.

In the whole sample the variance of the entrance scores gives $14.6 \%$ of the regular average/grade point average, the consolidated indicator of the cognitive skills of the input competence survey explains $14.5 \%$ of the regular average/grade point average. The variance of self-reflexion concerning the thinking skills is significant but not outstanding; it explains 3\% of the variance. We employed the regression analysis on the subsamples of dual and nondual students; we did not find significant differences between the subsamples.

In summary, the input competence survey has a similar predictive power to the entrance examination scores. The remaining part of the individual differences in the learning outcomes could not be explained by the instruments.

We chose a subsample of the nondual students which had the same distribution as that of the dual students in order to test the hypothesis (3). The fitting process was based on the number of students who started the semester, the entrance exam scores, the distribution of the consolidated indicator of the cognitive skills of the input competence survey.

In the fitted sample we have not found any significant differences based on regular average/grade point average at the end of the first academic year (average: dual: 3.8; nondual: 3.62; n.s.), neither considering the average of the last completed semester (average: dual: 3.71 ; nondual: 3.73 ; n.s.)

This shows that students with higher skill levels can be successful in the nondual education as well. Therefore, in this respect, they are given equal opportunities.

\section{Summary}

Our examinations confirmed that the students who take part in the dual education have above-average cognitive skills and motivation even at the beginning of their university studies. It is combined with other factors e.g., stricter selection process, higher learning outcome requirements results in significant differences in learning success which appears in the higher credit index. 
The students who do not take part in the dual training, but have the same abilities are similarly successful in learning. It is possible that their success in learning and comparing themselves to their peers compensate them for the lack of factors which support the dual students we mentioned in the introduction.

Based on our investigations we could found little about the individual differences in the in-learning success. We hope that with our further surveys (thus the questionnaire which explores the motivation and its changes, by obtaining data about sociocultural background) we endeavour to get a more precise explanation, and give guidelines to increase the efficiency of the currently ongoing intervention programmes (Török, Brindza, Hercz, Koltói, Pap-Szigeti and Rigó 2016).

\section{Acknowledgments}

This research is supported by EFOP-3.6.1-16-2016-00006 "The development and enhancement of the research potential at John von Neumann University" project. The Project is supported by the Hungarian Government and co-financed by the European Social Fund.

\section{References}

A Bizottság közleménye az Európai Parlamentnek, a Tanácsnak, a Gazdasági és Szociális Bizottságnak és a Régiók Bizottságának Az európai felsőoktatási rendszerek által az intelligens, fenntartható és inkluzív növekedés terén tett hozzájárulás növelése. [Communication from the Commission to the European Parliament, the Council, the European Economic and Social Committee and Committee of the Regions on a renewed EU agenda for higher education aiming to increase the contribution to the sustainable and inclusive development. ] Brüsszel, 2017. 05. 30. COM (2017) 247 final

Hercz, M. - Koltói, L. - Pap-Szigeti, R. - Török, E. (2014): Assessing competencies of freshmen: an on-line measurement in the college. Paper presented at 6th International Scientific and Expert Conference TEAM 2014. Technique, Education, Agriculture \& Management. Kecskemét, November 10th - 11th 2014.

Nagy Dorottya - Török Erika - Angeli Eliza (2019): A duális képzésü hallgatók szakmai fejlődésének követése és értékelése. [Tracking and assessment of dual students] Gradus, 6:(1) 57-62.

Pap-Szigeti Róbert (2018): Szoftver- és mérőeszköz-fejlesztés programozási ismeretek és készségek értékelésére. Gradus, 5:(2) 355-359. [Software and instrument development and assessment of skills]

Pogatsnik, M. (2019): Dual Education: The Win-Win Model of Collaboration between Universities and Industry https://doi.org/10.3991/ijep.v8i3.8111 (2019.10.15.)

Török Erika - Brindza Attila - Hercz Mária - Koltói Lillla - Pap-Szigeti Róbert - Rigó Róbert (2016): TALENTUM: hallgatói sikerességet támogató és tanulást segítő pilot program a Kecskeméti Főiskolán. [TALENTUM Programme helping students‘ learning success at Kecskemét college] In: Fodorné Tóth Krisztina (szerk.): Felsőoktatási kihívások. Alkalmazkodás stratégiai partnerségben. MELLearN Felsőoktatási Hálózat az életen át tartó tanulásért Egyesület, Pécs. 76-85.

Török Erika - Pap-Szigeti Róbert - Ailer Piroska - Palkovics László (2014): A Kecskeméti Főiskola duális képzésének monitoring vizsgálata a hallgatók visszajelzései alapján. [Monitoring dual training based on students‘ feedback ]A jövő jármüve, 2014:(1-2), 32-36. 